\title{
Penggunaan Metode Risk Based Bank Rating (RBBR) Untuk Menilai Tingkat Kesehatan Bank Pada PT. Bank Rakyat Indonesia, Tbk
}

\author{
Jamaludin ${ }^{*}$ \\ *) dosen universitas pamulang, email :. dosen01020@unpam.ac.id
}

\section{ARTICLES \\ INFORMATION}

ABSTRACT

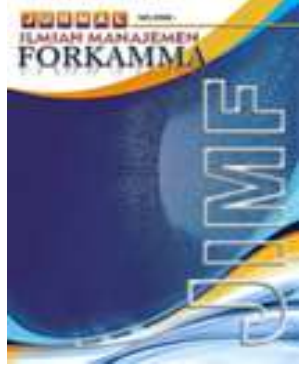

JURNAL ILMIAH MANAJEMEN FORKAMMA

Vol.3, No.2, Maret 2020

Halaman : $109-130$

(C) LPPM \& FORKAMMA

Prodi Magister Manajemen UNVERSITAS PAMULANG

ISSN (online) : 2599-171X

ISSN (print) : 2598-9545

\section{Keyword :}

Tingkat Kesehatan bank, Metode Risk Based Bank Rating.

JEL. classification :

O15,

Contact Author :

PRODI

MAGISTER MANAJEMEN \& FORKAMMA UNPAM

JL.Surya Kencana No.1 Pamulang

Tangerang Selatan - Banten

Telp. (021) 7412566, Fax (021) 7412491 Email :

jurnalforkamma.unpam@gmail.com
Tujuan dari penelitian ini untuk mengetahui tingkat kesehatan pada PT. BRI Tbk. dengan menggunakan pendekatan RBBR (Risk Based Bank Rating) pada tahun 20092018. Adapun Jenis penelitian ini adalah penelitian deskriptif dengan pendekatan kuantitatif. Variable yang digunakan adalah Risk Profile, faktor Good Corporate Governance, faktor Earnings, faktor Capital. Hasil penelitian bahwa tingkat kesehatan BRI pada tahun 2009 sampai tahun 2018 dengan menggunakan pendekatan RBBR adalah sehat. Faktor Risk Profile yang dinilai melalui NPL dan LDR, secara keseluruhan menggambarkan pengelolaan risiko yang telah dilaksanakan dengan baik. Faktor Good Corporate Governance BRI sudah memiliki dan menerapkan tata kelola perusahaan dengan sangat baik. Faktor Earnings atau Rentabilitas yang penilaiannya terdiri dari ROA dan NIM mengalami kenaikan dan hal ini menandakan bertambahnya jumlah aset yang dimiliki BRI diikuti dengan bertambahnya keuntungan yang didapat oleh BRI. Dengan menggunakan indikator CAR, peneliti membuktikan bahwa BRI memiliki faktor Capital yang baik, yaitu diatas ketentuan Bank Indonesia sebesar 8\%.

The purpose of this study was to determine the level of health at PT. BRI Tbk. by using the RBBR (Risk Based Bank Rating) approach in 2009-2018. The type of this research is a descriptive study with a quantitative approach. Variables used are Risk Profile, Good Corporate Governance factor, Earnings factor, Capital factor. The results of the study that the level of health of BRI in 2009 to 2018 using the RBBR approach is healthy. Risk Profile factors assessed through NPL and LDR, overall describe the risk management that has been carried out properly. Good Corporate Governance Factors BRI already has and implements corporate governance very well. Earnings or Profitability Factors whose appraisal consists of ROA and NIM have increased and this indicates an increase in the number of assets owned by BRI followed by increased profits obtained by $B R I$. By using the CAR indicator, the researchers prove that BRI has a good Capital factor, which is above the Bank Indonesia regulation of $8 \%$. 


\section{A. PENDAHULUAN}

Bank memiliki tujuan utama berupa menghimpun dan menyalurkan uang kepada masyarakat serta penukaran uang, dengan demikian bahwa bank cukup dikenal dengan dengan meja tempat penukaran uang. Dan di dunia modern saat ini sering kita kenal dengan perdaganagan valutas asing (valas). Operasional perbankan kemudian berkembang lebih lengkap menjadi tempat penitipan uang atau yang sekarang disebut sebagai kegiatan simpanan. Berikutnya kegiatan perbankan bertambah lagi dengan kegiatan peminjaman uang (memberikan kredit). Uang yang dititipkan masyarakat ke bank dalam bentuk simpanan oleh perbankan dipinjamkan kembali ke masyarakat yang membutuhkan dalam bentuk pinjaman atau kredit.

Seiring berjalannya waktu jasa perbankan mulai merambah dari berbagai kegiatan bisnis lainnya sesuai dengan kebutuhan nasabah/masyarakat. Dengan demikian peran dunia perbankan semakin menjadi daya tarik bagi masyarakat akan jasa yang ditawarkan kepada calon nasabah baik pada Negara maju maupun kenegara yang berkembang. Seperti jasa transfer, jasa penagihan surat berharga, jasa letter of credit (L/C), bank garansi dan jasa yang cukup popular adalah jasa pinjaman/kredit. Belum lagi terdapat jasa yang paling mudah bagi nasabah yaitu jasa kartu kredit yang sudah sedikit menggeser fungsi dari uang dalam jasa pembayaran, karena masyarakat sebagian sudah melakukan transaksi dengan debit atau kartu kredit dan tidak lagi menggunakan uang cash. Itu artinya bahwa sebagian besar pelayan yang ditawarkan perbankan sudah mendominasi dan mampu merubah kebiasaan lama dari masyarakat dalam kaitanya denga kegiatan bisnis masyarakat. Dengan demikian maraknya jenis transaksi seperti itu secara tiddak langsung sudah menentukan suatu Negara dan masyakat tidak lagi menutup diri akan perubahan kebiasaan tersebut.

PT. BRI Tbk. Merupakan salah satu BUMN milik pemerintah menyediakan solusi perbankan melalui produk dan layanan terintegrasi yang didukung teknologi digital untuk memenuhi kebutuhan seluruh segmentasi nasabah. Perjalanan bisnis PT. Bank Rakyat Indonesia, Tbk sejak tahun 1895 di Purwokerto, Jawa Tengah yang dirintis oleh Raden Aria Wiriatmaja yang pada dasarnya hanya mengelola dana masjid dan untuk disalurkan kepada calon nasabah/masyarakat. Diawal berdiri ada beberapa nama dari BRI, seperti De Poerwokertosche Hulp en Spaarbank der Indlandsche Hoofden, Hulp en Spaarbank der Indlandsche Bestuurs Ambtenareen, Syomin Ginko, dan akhirnya secara resmi diberi nama Bank Rakyat Indonesia sejak 18 Desember 1968 berdasarkan UU No. 21 tahun 1968.

Sejak berdiri BRI hanya focus pada bisnis yang bergerak pada UMKM, dan pelopor microfinance di Indonesia. Komitemen tersebut selalu dijaga hingga kini, dari awal BRI cukup konsisten terhadap pencapaiannya dan berhasil mempertahankan eksistensinya dengan prestasi sebagai bank yang profitnya terbesar dari bank yang lainnya selama 13 tahun secara terus menerus. . pencapaian tersebut merupakan bukti dan hasil dari kinerja bank BRI dalam memberikan pelayanan terbaik untuk nasabah/masyarakat, karena selama berdiri BRI tidak henti-hentinya berinovasi dan melakaukan pengembangan produk dalam menarik hati nasabah. Demi eksistensinya PT BRI Tbk sellau memberikan layanan prima pada nasabahnya dalam bukti memberikan layanan perbankan yang berbasis teknologi dari pusat hingga ke pelosok desa dari sabang sampai merauke dan terus menyediakan pelayan yang sesuai dengan kebutuhan masyarakat dan nasabah pada khususnya.

Modal utama dari jasa pelayanan adalah kepercayaan (trust), Bank BRI selalu menjadi salah satu bank milik pemerintah yang sanmpai sekarang tingkat kepercayaan masyarakat semakin meningkat. Karena biargimana pun masyakat masih menaruh harapan besar pada dunia perbankan dalam mengamankan uang mereka, sehingga 
disini Bank BRI sangat peduli dengan hal tersebut, dan selalu berusaha menjadi salah satu yang selalu menjadi idola bagi masyakarat. Dalam meningkatkan kepercayaan tersebut, tentu harus memperhatikan dan selalu memelihara tingkat kesehatan bank terutama selalu menjaga likuiditasnya dalam memenuhi kewajibannya dan menjaga kinerja agar selalu menjadi bank yang dapat dipercaya oleh nasabah.

Tingkat kesehatan bank itu secara umum dapat dilihat dari apakah bank itu menjalankan fungsinya dengan baik/tidak. Menurut Permana, bank yang sehat merupakan bank yang selalu menjaga serta memelihara kepercayaan nasabah/masyarakat, fungsi intermediasinya dijalankan dengan baik, mempermudah proses pembayaran nasabah, dan dapat digunakan pemerintah dalam menetapkan dan membuat kebijakan terutama dalam membuat kebijakan moneter dalam mengontrol jumlah uang beredar (Permana, 2012:2).

Tingkat kesehatan bank selalu menjadi perhatian khusus supaya selalu memberikan pelayanan terbaik (prima) bagi nasabah/masyarakat, karena jika bank tidak sehat akan membahayakan perbankan dan semua pihak yang terlibat dan pihak lain juga Negara. Kriteria tingkat kesehatan bank dapat dilihat dari berbagai penilaian seperti sangat sehat, sehat, cukup sehat, kurang sehat atau tidak sehat.

Tujuan utama dari pengawasan bank adalah untuk memantau dan memeriksa yang sesuai dengan ketentuan perbankan yang berlaku. Selain itu juga digunakan untuk mengukur kinerja dan tingkat kesehatan dari bank. Tingkat kesehatan bank dilakukan untuk melihat kemampuan suatu bank dalam kegiatan operasionalnya secara baik dan dalam memenuhi semua kewajiban dengan baik sesuai dengan undang-undnag perbankan. Bank sentral (BI) menerbitkan Peraturan Bank Indonesia No.13/1/PBI/2011 mengenai tingkat kesehatan bank yang diukur dengan menggunakan metode Risk Based Bank Rating (RBBR). RBBR terdiri dari empat faktor yakni, profil risiko, good corporate governance, rentabilitas (earning), dan permodalan.

Menurut Peraturan Bank Sentral (BI) No. 13/ 1/ PBI/ 2011 profil risiko merupakan penilaian terhadap risiko inheren dan kualitas penerapan manajemen risiko dalam operasional bank yang dilakukan terhadap 8 (delapan) resiko yaitu, risiko kredit, pasar, likuiditas, operasional, hukum, strategik, kepatuhan dan reputasi. Penelitian ini mengukur risiko kredit menggunakan rasio Non Performing Loan dan rasio Loan to Deposit Ratio untuk mengukur resiko liquiditas.

Dengan menganalisis laporan Good Corporate Governance berlandaskan pada Peraturan Bank Sentral (BI) No.13/1/PBI/2011 dengan mencari laporan tahunan yang dipublikasikan dan menetapkan penilaian yang dilakukan oleh bank berdasarkan cara self assessment. unsur earning merupakan penilaian meliputi kinerja, sumber, kesinambungan, dan manajemen rentabilitas, rasio dari kinerja rentabilitas yakni Return On Asset dan Net Interest Margin.

Riyadi (2006:171) meyatakan setiap bank kegiatan operasinya di Indonesia wajib menyediakan berupa Kewajiban Penyediaan Modal Minimum (KPMM). Tinggi rendahnya KPMM/CAR suatu bank akan dipengaruhi oleh 2 faktor utama yaitu besarnya modal yang dimiliki bank dan jumlah Aktiva Tertimbang Menurut Risiko (ATMR) yang dikelola oleh bank. Karena penilaian faktor permodalan didasarkan pada rasio Modal terhadap ATMR. Penilaian faktor capital diukur dengan menggunakan CAR.

Tabel Data NPL, LDR, GCG, ROA, NIM, dan CAR PT. BRI, Tbk tahun 2009-2018

\begin{tabular}{|c|c|c|c|c|c|c|}
\hline Tahun & NPL & LDR & GCG & ROA & NIM & CAR \\
\hline 2009 & 3,53 & 80,69 & 1,35 & 3,12 & 7,71 & 13,20 \\
\hline 2010 & 2,01 & 75,17 & 1,45 & 3,69 & 8,66 & 13,76 \\
\hline 2011 & 1,76 & 76,13 & 1,30 & 3,99 & 7,96 & 14,96 \\
\hline 2012 & 1,44 & 79,86 & 1,31 & 4,33 & 7,31 & 16,95 \\
\hline
\end{tabular}




\begin{tabular}{|l|c|c|c|c|c|c|}
2013 & 1,27 & 88,55 & 1,29 & 4,46 & 7,76 & 16,99 \\
\hline 2014 & 1,26 & 81,75 & 1,14 & 4,84 & 7,07 & 18,31 \\
\hline 2015 & 1,17 & 86,93 & 1,17 & 3,70 & 7,45 & 20,59 \\
\hline 2016 & 1,06 & 87,84 & 2 & 3,39 & 6,60 & 22,91 \\
\hline 2017 & 1,10 & 88,18 & 2 & 3,28 & 6,47 & 22,96 \\
\hline 2018 & 1,17 & 89,58 & 2 & 3,22 & 6,59 & 21,21 \\
\hline
\end{tabular}

Sumber : Data diolah (2019)

Dari hasil tabel diatas, nilai risk profile yaitu NPL pada tahun 2009 adalah 3,53\% tetapi mengalami penurunan berturut-turut sampai tahun 2016 dan pada tahun 2017 mengalami kenaikan menjadi 1,10\% sedangkan nilai LDR mengalami fluktuasi dari tahun 2009 sebesar $80,69 \%$ menjadi $89,58 \%$ pada 2018 . Nilai GCG mengalami fluktuasi dari tahun 2009 sebesar 1,35 menjadi 2,0 pada tahun 2018. Nilai earning yaitu ROA mengalami fluktuasi dari tahun 2009 sebesar $3,12 \%$ menjadi $3,22 \%$ pada tahun 2018, sedangkan NIM mengalami fuktuasi pada tahun 2009 sebesar $7,71 \%$ sampai $20157,45 \%$ dan mengalami penurunan berturut-turut sampai pada 2018 menjadi $6,54 \%$. Nilai capital yaitu CAR mengalami kenaikan berturut-turut dari 2009 sebesar $13,20 \%$ menjadi $21,21 \%$ pada tahun 2018. Dari latar belakang tersbut, maka peneliti melakukan penelitian dengan tema "PENGGUNAAN METODE RISK BASED BANK RATING (RBBR) UNTUK MENILAI TINGKAT KESEHATAN BANK PADA PT. BANK RAKYAT INDONESIA, TBK".

\section{B. KAJIAN LITERATUR}

\section{Manajemen Keuangan}

Menurut Fahmi (2015:2), manajemen keuangan merupakan kolaborai dari ilmu/seni yang membahas, mengkaji dan menganalisis bagaimana seorang manajer keuangan dalam memanfaatkan semua sumber daya yang dimilkioleh perusahaan dalam menghimpun dana, pengelolaan dana, dan menyalurkan dana perusahaan untuk tujuan dalam meningkatkan profit dan kemakmuran bagi investor/pemegang saham dan keberlanjutan usaha perusahaan dalam jangka panjang.

\section{Laporan Keuangan}

Laporan keuangan bertujuan memberikan informasi finansial perusahaan baik kepada owner, pihak manajemen, dan pihak lain yang berkepentingan dengan perusahaan. Semua perusahaan yang bergerak di dunia perbankan/non bank, perusahaan BUMN atau swasta, setiap periode (tahunan) selalu menginformasikan dan melaporkan semua kegiatan finansialnya (Kasmir, 2017: 280)

\section{Pengertian Bank}

Menurut Kasmir (2014: 3) bank merupakan badan Usaha/lembaga keuangan yang kegiatan usahanya adalah menghimpun dan menyalurkan kembali dana tersebut ke masyarakat serta memberikan jasa pelayanan bank lainnya kepada nasabah/masyarakat. Menurut UU No. 10 Tahun 1998, bank merupakan lembaga yang usahanya menghimpun dana dalam bentuk simpanan dan menyalurkannya dalam bentuk kredit dan/atau bentukbentuk lainnya kepada masyarakat dalam rangka meningkatkan taraf hidup rakyat banyak.

\section{Kesehatan Bank}

Menurut Peraturan Bank Indonesia No. 13/1/PBI/2011 "Tingkat Kesehatan Bank adalah hasil penilaian kondisi Bank yang dilakukan terhadap risiko dan kinerja Bank". Kesehatan bank merupakan kemampuan suatu bank dalam melakukan operasional 
perbankan secara normal, mampu memenuhi kewajibannya dengan baik sesuai dengan peraturan perbankan (Triandaru dan Budisantoso, 2014: 51). Kinerja bank dapat diketahui jika melakukan analisis mengenai tingkat kesehatan bank supaya menunjukan bank tersebut dikatakan kriteria sehat atau tidak.

Menurut Rivai, dkk (2012: 465) Kesehatan/kondisi keuangan dan non keuangan bank merupakan kepentingan semua pihak terkait, berupa owner, pihak manajemen bank, bank pemerintah (Bank Indonesia) dan para pengguna jasa perbankan. Hal tersebut dilakukan untuk mengevalusi kinerja bank dalam menerapkan prinsip kehati-hatian, kepatuhan terhadap aturan dan manajemen resiko.

Tabel Kriteria Penetapan Peringkat Komposit

\begin{tabular}{|c|l|}
\hline $\begin{array}{c}\text { Peringkat } \\
\text { Komposit }\end{array}$ & \multicolumn{1}{c|}{ Keterangan } \\
\hline 1 & $\begin{array}{l}\text { Dengan kondisi bank yang sangat sehat, maka bank akan mampu } \\
\text { mengahdapai pengaruh yang merugikan bank/negatif dan perubahan } \\
\text { situasi usaha/bisnis bank serta faktor eksternal lainnya. }\end{array}$ \\
\hline 2 & $\begin{array}{l}\text { kondisi bank yang secara umum dikatakan sehat. dapat dinilai } \\
\text { mampu menghadapi pengaruh negatif yang signifikan dan perubahan } \\
\text { situasi usaha/bisnis bank serta faktor eksternal lainnya. }\end{array}$ \\
\hline 3 & $\begin{array}{l}\text { Dengan kondisi bank yang cukup sehat, maka bank akan mampu } \\
\text { mengahdapai pengaruh yang merugikan bank/negatif dan perubahan } \\
\text { situasi usaha/bisnis bank serta faktor eksternal lainnya. }\end{array}$ \\
\hline 4 & $\begin{array}{l}\text { kondisi bank yang secara umum kurang sehat sehingga dinilai kurang } \\
\text { mampu mengahdapai pengaruh yang merugikan bank/negatif dan } \\
\text { perubahan situasi usaha/bisnis bank serta faktor eksternal lainnya. }\end{array}$ \\
\hline 5 & $\begin{array}{l}\text { Keadaan bank yang secara umum dikatakan tidak sehat sehingga } \\
\text { dinilai sangat tidak mampu mengahdapai pengaruh yang merugikan } \\
\text { bank/negatif dan perubahan situasi usaha/bisnis bank serta faktor } \\
\text { eksternal lainnya. }\end{array}$ \\
\hline
\end{tabular}

Sumber: Peraturan BI No. 13/I/PBI/2011

\section{Unsur Level Kesehatan Bank}

Unsur level kesehatan bank yaitu Risk Governance Earning Capital : Pada Peraturan Bank Indonesia Nomor. 13/1/PBI/2011 dan SE No. 13/ 24/ DPNP tanggal 2510-2011 yang menjadi tolak ukurnya adalah 1) Risk Profile, 2) Good Corporate Governance, 3) Rentabilitas (Earnings), dan 4) Permodalan:

1) Risk profile

Penilaian ini merupakan penilaian terhadap risiko Inheren dan kualitas implementasi pengelolaan (manajemen) risiko dalam kegiatan operasional bank. Hal ini terbagai 8 bagian sebagai berikut:

a. Resiko Kredit

merupakan risiko yang timbul akibat ketidakmampuan nasabah dalam membayar pinjamannya kepada bank sesuai dengan tanggal jatuh tempo yang telah disepakati kedua belah pihak. Jika kredit semakin menigkat, makan resiko inheren akan semakin tinggi pula. misalnya peningkatan kredit diatas pertumbuhan ratarata industri. Faktor lain yang dapat meningkatkan risiko inheren kredit adalah pengembangan pemasaran kredit pada daerah baru, memasarkan produk baru, atau memasarkan produk lama dengan fitur baru di bidang perkreditan, pengembangan produk, atau segmen kredit baru seperti kredit segmen mikro, kartu kredit dan sebagainya. rasio kredit dihitung dengan menggunakan rumus berikut. 


$$
N P L=\frac{\text { Kredit bermasalah }}{\text { Total Kredit }} \times 100 \%
$$

Jika NPL semakin rendah maka tingkat kesehatan bak semakin sehat (kriteria dikatakan sangat sehat jika hasilnya $<2$ )

b. Risiko pasar

Resiko ini muncul karena rendah dan menurunnya nilai investasi terhadap konsisi pasar/ekonomi. Dengan rumus seperti berikut:

$$
I R R=\frac{R S A}{R S L} \times 100 \%
$$

Keterangan:

IRR : risiko tingkat suku bunga (Interest Rate Risk)

RSA : aktiva yang dapat berubah setelah tanggal jatuh waktu aktiva yang bersangkutan (Rate Sensitive Assets)

RSL : pasiva yang imbal hasilnya dapat berubah setelah tanggal jatuh waktu pasiva yang bersangkutan ((Rate Sensitive Liabilities)

c. Resiko Likuiditas

Resiko ini muncul akibat ketdak mampuan perusahaan dalam membayar kewajiban jangka pendeknya yang telah jatuh tempo. Berikut adalah cara menghitung rasio liquiditas:

1) Loan to Deposit Ratio (LDR)

Loan to Deposit Ratio merupakan rasio tingginya jumlah kredit yang diberikan kepada nasabah dan banyaknya jumlah dana/pinjaman dari berbagai sumber. Artinta rasiona rasio yang menunjukan tingginya utang suatu perusahaan. Rumus LDR adalah

$$
L D R=\frac{\text { Total Kredit }}{\text { Dana Pihak Ketiga }} \times 100 \%
$$

Resiko ini dikatakan sangat sehat ketika hasil $70 \%-85 \%$.

2) Loan to Asset Ratio (LAR)

Loan to Asset Ratio merupakan kemampuan bank dalam memberikan kredit dengan asset yang dimiliki perusahaan. LAR dapat dihitung dengan cara:

$$
L A R=\frac{\text { Total Kredit }}{\text { Total Asset }} \times 100 \%
$$

3) Rasio kas (Cash Ratio)

Rasio kas merupakan perbandingan total kas yang dimiliki oleh bank/perusahaan dan total kewajiban yang segera dapat ditagih. Rumuas Rasio kas.

$$
\text { Cash Ratio }=\frac{\text { Alat }- \text { alat likuid yang dikuasai }}{\text { Dana pihak ketiga }} \times 100 \%
$$


d. Risiko operasional

Resiko ini muncul akibat ketidakcukupan/tidak berfungsinya proses internal, human error, system error, dan/atau adanya kejadian eksternal yang berdampak negatif pada operasional bank.

e. Resiko law

Resiko ini muncul akibat tuntutan hukum lemahnya kekuatan hukum. Dan timbulnya karena belum tersedianya kebiijakan pendukung dan lemaknya perikatan (tidak terpenuhinya syarat sahnya kontrak dan jaminan yang tidakmemadai)

f. Resiko strategi

Resiko ini muncuk karena ketidaktepatan cara dan strategi yang diambil dan atau kegagalan membaca kondisi lingkungan usahah/bisnis

g. Resiko ketaatan/kepatuhan

Resiko ini muncul akibat bank tidak mematuhi peraturan dan undang-undang yang berlaku.

h. Resiko reputasi dan trust

Resiko ini muncul akibat adanya ketidakpercayaan nasabah/stakeholder karena berpandnagan negative terhadap bank/perusahaan.

2) Good Corporate Governance (GCG)

Hal ini merupakan penggunaan fungsi organisasi yang berdasarkan manajemen yang baik, dalam artian pelaksanaan prinsip Good Corporate Governance yang bepedoman pada aturan yang dibuat oleh $\mathrm{BI}$ dengan memperhatikan karakteristik, dan komplesitas bisnis dunia perbankan. GCG biasanya mencerminkan bagian manajemen dari Capital, Asset Quality, Management, Earning, Liquidity, dan Sensitivity to Market risk (CAMELS) namun telah disempurnakan. Untuk mengukur GCG dapat digunakan dengan metode Self Assesment karena berdasarkan Surat Edaran Bank Indonesia Nomor. 15/15/DPNP Tahun 2013 mewajibkan Self Assesment (SA) dalam mengukur GCG. SA merupakan penilaian sendiri terhadap masing-masing bank atas persetujuan dewan direksi dengan mengacu pada peringkat komposit pada Surat Edaran Bank Indonesia Nomor. 15/15/DPNP Tahun 2013. Jika nilai komposit pada bank semakin rendah, maka bank tersebut dikatakan sehat. Kriteria komponen dikatakan sangat sehat jika hasilnya $<1,5$.

3) Earnings (Rentabilitas)

Penilaian ini bertujuan untuk mengukur seberapa efisien usaha dan keuntungan yang diperoleh oleh suatu bank. Untuk menghitung earning (rentabilitas) dapat menggunakan indicator sebagai berikut:

a. Return On Assets (ROA)

Menurut Kuncoro dan Suhardjono (2011: 506) ROA merupakan kemampuan perusahaan/bank dalam memperoleh profit/keuntungan dari mengelola asset-aset yang dimiliki oleh bank tersebut. Cara menghitung ROA adalag berikut:

$$
\text { ROA }=\frac{\text { Laba sebelum pajak }}{\text { Total aset }} \times 100 \%
$$

Jika hasil dari perhitungan ROA semakin meningkat, maka bank tersebut dikatakan semakin sehat. Jika raio bank $>2 \%$ makan dikatakan sangat sehat.

b. Return On Equity (ROE)

menurut Syafri Harahap menyatakan bahwa ROE merupakan kemampuan perusahaan/bank dalam memperoleh laba bersih bila dibandingkan dengan modal owner/pemilik. Rumus ROE seperti berikut ini. 


$$
\text { ROE }=\frac{\text { Laba Setelah } \text { Pajak }}{\text { Rata }- \text { rata modal inti }} \times 100 \%
$$

c. Net Interest Margin/NIM

Net Interest Margin/NIM untuk mengukur seberapa besar perbedaan pendapatan dari bunga yang dihasilkan dengan nilai Bungan yang telah dibayarkan. Rumus untuk menghitung NIM.

$$
N I M=\frac{\text { Pendapatan bunga bersih }}{\text { Rata }- \text { rata aktiva produktif }} \times 100 \%
$$

Jika hasil perhitungan NIM semakin tinggi makan semakin sehat. Atau ketika standar rasionya $>5 \%$.

d. Beban Operasional terhadap pendapatan operasional/BOPO

Maksud dari BOPO adalah jika pendapatan yang diperoleh oleh bank lebih tinggi dari biaya operasional, itu artinya bank akan memperoleh keuntungan yang lebih besar. Rumus BOPO adalah.

$$
\text { BOPO }=\frac{\text { Beban Operasional }}{\text { Pendapatan Operasional }} \times 100 \%
$$

Jika biaya operasional bank semakin rendah, makan dikatakan sehat. Atau ketika rasio BOPO ini memiliki nilai $<94 \%$.

4) Capital (Permodalan)

Jika Rasio kecukupan modal (Capital Adequacy Ratio/CAR) menandakan hal yang baik bagi bank. CAR yang tinggi, maka bank dengan mudah melakukan ekspansi kedepan untuk jangka panjang. Modal bank merupakan sejumlah uang/dana atau dalam bentuk lainya yang dimiliki/dikuasai oleh lembaga usaha (Wayan, 2013). Rumus menghitung CAR.

$$
\text { CAR }=\frac{\text { Modal }}{\text { ATMR }} \times 100 \%
$$

Bank dikatakan sangat sehat jika rasio Kewajiban Penyediaan Modal Minimum >12\%.

\section{METODOLOGIPENELITIAN}

\section{Sumber Data}

Data yang digunakan dalam penelitian ini adalah data sekunder yang bersumber dari laporan tahunan laporan keuangan PT Bank Rakyat Indonesia Tbk. Berupa:

- Laporan keuangan posisi hasil konsolidasi per tanggal 31 Desember 2009-2018.

- Laporan laba rugi dan penghasilan komprehensif lain hasil konsolidasi per tanggal 31 Desember 2009-2018.

- Catatan atas laporan keuangan hasil konsolidasi per tanggal 31 Desember 20092018. 
Teknik Pengumpulan Data

Setiap penelitian pasti memiliki teknik/cara dalam mengumpulkan data risetnya. Begitupun dalam penelitian ini. teknik pengumpulan dalam penelitian ini adalah dokumentasi. Metode dokumentasi adalah objek yang diperhatikan (ditatap) dalam memperoleh informasi berupa tiga macam sumber, yaitu tulisan (paper), tempat (place), dan kertas atau orang (people) (Arikunto, 2014: 201). Dokumentasi yang digunakan dalam penelitian ini adalah berupa dokumen laporan keuangan PT. BRI, Tbk periode 2009-2018 (diakses pada www.bri.co.id)

\section{Teknik Analisis Data}

Penelitian ini menggunakan teknik teknik analisis tingkat kesehatan bank dengan pendekatan Metode Risk Based Bank Rating/RBBR yang cakupannya faktor seperti berikut: Profil Risiko (Risk profile), Good Corporate Governance/GCG, Rentabilitas/Earnings dan Permodalan/Capital (metode RGEC). Penelitian ini dianalisis secara. Berikut adalah langkah yang digunakan dalam menganalisis metode RGEC:

1) Mengumpulkan data laporan keuangan PT. Bank BRI Tbk periode rtahun 2009-2018.

2) Melakukan Analisis Profile Risiko/Risk Profile

a. Menghitung risiko kredit, dengan menghitung rasio Non Perfoming Loan /NPL dengan menggunakan rumus berikut.

$$
N P L=\frac{\text { Kredit Bermasalah }}{\text { Total Kredit }} \times 100 \%
$$

Tabel Matrik Kriteria Penetapan Peringkat Komponen Resiko Kredit

\begin{tabular}{|c|c|c|}
\hline Peringkat & Keterangan kinerja & Standar Rasio resiko kredit \\
\hline 1 & Sangat Sehat & $\mathrm{NPL}<2 \%$ \\
\hline 2 & Sehat & $2 \% \leq \mathrm{NPL}<5 \%$ \\
\hline 3 & Cukup Sehat & $5 \% \leq \mathrm{NPL}<8 \%$ \\
\hline 4 & Kurang Sehat & $8 \% \leq \mathrm{NPL} 12 \%$ \\
\hline 5 & Tidak Sehat & $\mathrm{NPL} \geq 12 \%$ \\
\hline
\end{tabular}

Sumber: Lampiran SE BI 13/24/DPNP/2011

b. Menghitung resiko likuiditas, dengan menghitung rasio Loan to Deposit Ratio/LDR. Berikut rumus dari LDR.

$$
L D R=\frac{\text { Total Kredit }}{\text { Dana Pihak Ketiga }} \times 100 \%
$$

Tabel Matrik Kriteria Penetapan Peringkat Komponen Resiko Likuiditas

\begin{tabular}{|c|c|c|}
\hline Peringkat & Keterangan Kinerja & Standar Rasio Likuiditas \\
\hline 1 & Sangat Sehat & $50 \%<$ LDR $\leq 75 \%$ \\
\hline 2 & Sehat & $75 \%<$ LDR $\leq 85 \%$ \\
\hline 3 & Cukup Sehat & $85 \%<$ LDR $\leq 100 \%$ \\
\hline 4 & Kurang Sehat & $100 \%<$ LDR $\leq 120 \%$ \\
\hline 5 & Tidak Sehat & LDR $>120 \%$ \\
\hline
\end{tabular}

Sumber: Surat Edaran Bank Indonesia 13/24/DPNP/2011 
3) Analisis Good Corporate Governance (GCG)

Analisis GCG bank dengan menganalisis hasil self assessment nya.

Tabel Matrik Kriteria dalam Penetapan Peringkat Komponen Risiko GCG

\begin{tabular}{|c|c|c|}
\hline Peringkat & Keterangan Kinerja & Resiko Rasio GCG \\
\hline 1 & Sangat Baik & Nilai Komposit $<1,5$ \\
\hline 2 & Baik & $1,5<$ Nilai Komposit $<2,5$ \\
\hline 3 & Cukup Baik & $2,5<$ Nilai Komposit $<3,5$ \\
\hline 4 & Kurang Baik & $3,5<$ Nilai Komposit $<4,5$ \\
\hline 5 & Tidak Baik & Nilai Komposit $>4,5$ \\
\hline
\end{tabular}

Sumber: Lampiran SE BI 13/24/DPNP/2011

4) Analisis Rentabilitas/profitabilitas (Earning)

Dalam menganalisis Rasio rentabilitas dapat menggunakan cara berikut ini:

a. Menghitung tingkat Return On Assets/ROA

$$
\text { ROA }=\frac{\text { Laba sebelum pajak }}{\text { Rata }- \text { rata total aset }} \times 100 \%
$$

Tabel Matrik Kriteria Penetapan Peringkat Komponen Risiko Rentabilitas

\begin{tabular}{|c|c|c|}
\hline Peringkat & Keterangan Kesehatan & Resiko Rasio rentabilitas \\
\hline 1 & Sangat Sehat & $2 \%<\mathrm{ROA}$ \\
\hline 2 & Sehat & $1,25 \%<\mathrm{ROA} \leq 2 \%$ \\
\hline 3 & Cukup Sehat & $0,5 \%<\mathrm{ROA} \leq 1,25 \%$ \\
\hline 4 & Kurang Sehat & $0 \%<\mathrm{ROA} \leq 0,5 \%$ \\
\hline 5 & Tidak Sehat & $\mathrm{ROA} \leq 0 \%$ \\
\hline
\end{tabular}

Sumber: Lampiran SE BI 13/24/DPNP/2011

b. Menghitung Net Interest Margin/NIM

$$
N I M=\frac{\text { Pendapatan bunga bersih }}{\text { Rata }- \text { rata aktiva produktif }} \times 100 \%
$$

Tabel Matrik Kriteria Penetapan Peringkat Komponen Risiko Rentabilitas (NIM)

\begin{tabular}{|c|c|c|}
\hline Peringkat & Keterangan sehat & Rasio \\
\hline 1 & Sangat Sehat & $3 \%<\mathrm{NIM}$ \\
\hline 2 & Sehat & $2 \%<\mathrm{NIM} \leq 3 \%$ \\
\hline 3 & Cukup Sehat & $1,5 \%<\mathrm{NIM} \leq 2 \%$ \\
\hline 4 & Kurang Sehat & $1 \%<\mathrm{NIM} \leq 1,5 \%$ \\
\hline 5 & Tidak Sehat & $\mathrm{NIM} \leq 1 \%$ \\
\hline
\end{tabular}

Sumber: Lampiran SE BI 13/24/DPNP/2011 
5) Analisis Permodalan/Capital

Rumus menghitung CAR.

$$
C A R=\frac{\text { Modal }}{\text { ATMR }} \times 100 \%
$$

Tabel Matrik Kriteria Penetapan Peringkat Komponen Faktor Permodalan

\begin{tabular}{|c|c|c|}
\hline Peringkat & Keterangan & Rasio \\
\hline 1 & Sangat Sehat & $12 \%<$ CAR \\
\hline 2 & Sehat & $9 \%<$ CAR $\leq 12 \%$ \\
\hline 3 & Cukup Sehat & $8 \%<$ CAR $\leq 9 \%$ \\
\hline 4 & Kurang Sehat & $6 \%<$ CAR $\leq 8 \%$ \\
\hline 5 & Tidak Sehat & CAR $\leq 6 \%$ \\
\hline
\end{tabular}

Sumber: Lampiran SE BI 13/24/DPNP/2011

6) Melakukan pemeringkatan tiap analisis dari Net Profit Loan, LDR, GCG, Return On Asset, NIM, dan Capital Adequacy Ratio.

7) Menetapkan peringkat komposit penilaian tingkat kesehatan bank dari tahun 2009 2018. Nilai komposit untuk rasio keuangan masing-masing komponen yang menempati peringkat komposit akan bernilai sebagai berikut :

a. Peringkat $1=$ tiap kali ceklist $x$ dengan 5

b. Peringkat $2=$ tiap kali ceklist $\times 4$

c. Peringkat $3=$ tiap kali ceklist $\times 3$

d. Peringkat $4=$ tiap kali ceklist $\times 2$

e. Peringkat $5=$ tiap kali ceklist $\times 1$

Setelah melakukan perkalian tiap ceklis, lalu mennetukan bobotnya dengan cara mempersentasekannya. Berikut bobot/persentase dalam menentukan peringkat komposit keseluruhan komponen:

Tabel Matrik Kriteria Penetapan Peringkat Komposit Tingkat Kesehatan Bank

\begin{tabular}{|c|c|c|}
\hline $\begin{array}{c}\text { Bobot } \\
(\%)\end{array}$ & $\begin{array}{c}\text { Peringkat } \\
\text { Komposit }\end{array}$ & Keterangan kesehatan \\
\hline $86-100$ & PK 1 & Sangat Sehat \\
\hline $71-85$ & PK 2 & Sehat \\
\hline $61-70$ & PK 3 & Cukup Sehat \\
\hline $41-60$ & PK 4 & Tidak Sehat \\
\hline$<40$ & PK 5 & \\
\hline
\end{tabular}

Sumber: Refmasari dan Setiawan (2014)

$$
\text { Peringkat Komposit }=\frac{\text { Jumlah nilai komposit }}{\text { Total nilai komposit keseluruhan }} \times 100 \%
$$

Kesimpulannya, dalam melihat tingkat kesehatan bank harus sesuai standar perhitungan sesuai dengan ketentuan yang dibuat oleh Bank Indonesia, harus berdasarkan rasio diatas. 
ISSN (print) : 2598-9545 \& ISSN (online) : 2599-171X

\section{HASIL DAN PEMBAHAS AN}

1. Profil Risiko (Risk Profile)

a. Risiko Non Performing Loan/NPL

Rasio ini menunjukan kemampuan dalam mengelola kredit macet dari keseluruahan kredit yang telah diberikan. Berikut adalah rasio NPL PT BRI, Tbk.

Tabel Tingkat Kesehatan BRI tahun 2009-2018 berdasarkan Rasio NPL

\begin{tabular}{|l|c|c|c|c|c|}
\hline TAHUN & $\begin{array}{c}\text { KREDIT } \\
\text { BERMASALAH }\end{array}$ & $\begin{array}{c}\text { TOTAL } \\
\text { KREDIT }\end{array}$ & NPL & PREDIKAT & PERINGKAT \\
\hline 2009 & 7.231 .660 & 205.037 .003 & 3,53 & Sehat & 2 \\
\hline 2010 & 4.957 .766 & 246.964 .238 & 2,01 & Sehat & 2 \\
\hline 2011 & 5.010 .108 & 285.406 .257 & 1,76 & $\begin{array}{c}\text { Sangat } \\
\text { Sehat }\end{array}$ & 1 \\
\hline 2012 & 5.059 .432 & 350.758 .262 & 1,44 & $\begin{array}{c}\text { Sangat } \\
\text { Sehat }\end{array}$ & 1 \\
\hline 2013 & 5.504 .271 & 434.316 .466 & 1,27 & $\begin{array}{c}\text { Sangat } \\
\text { Sehat }\end{array}$ & 1 \\
\hline 2014 & 6.219 .743 & 495.097 .288 & 1,26 & $\begin{array}{c}\text { Sangat } \\
\text { Sehat }\end{array}$ & 1 \\
\hline 2015 & 6.598 .838 & 564.480 .538 & 1,17 & $\begin{array}{c}\text { Sangat } \\
\text { Sehat }\end{array}$ & 1 \\
\hline 2016 & 6.790 .381 & 643.470 .975 & 1,06 & $\begin{array}{c}\text { Sangat } \\
\text { Sehat }\end{array}$ & 1 \\
\hline 2017 & 7.915 .978 & 718.982 .668 & 1,10 & $\begin{array}{c}\text { Sangat } \\
\text { Sehat }\end{array}$ & 1 \\
\hline 2018 & 9.631 .449 & 820.010 .157 & 1,17 & $\begin{array}{c}\text { Sangat } \\
\text { Sehat }\end{array}$ & 1 \\
\hline & Rerata & & 1,58 & $\begin{array}{c}\text { Sangat } \\
\text { Sehat }\end{array}$ & $\mathbf{1}$ \\
\hline
\end{tabular}

Sumber : data diolah (2019)

Selanjutnya, tabel diatas dapat dibuat grafik seperti berikut.

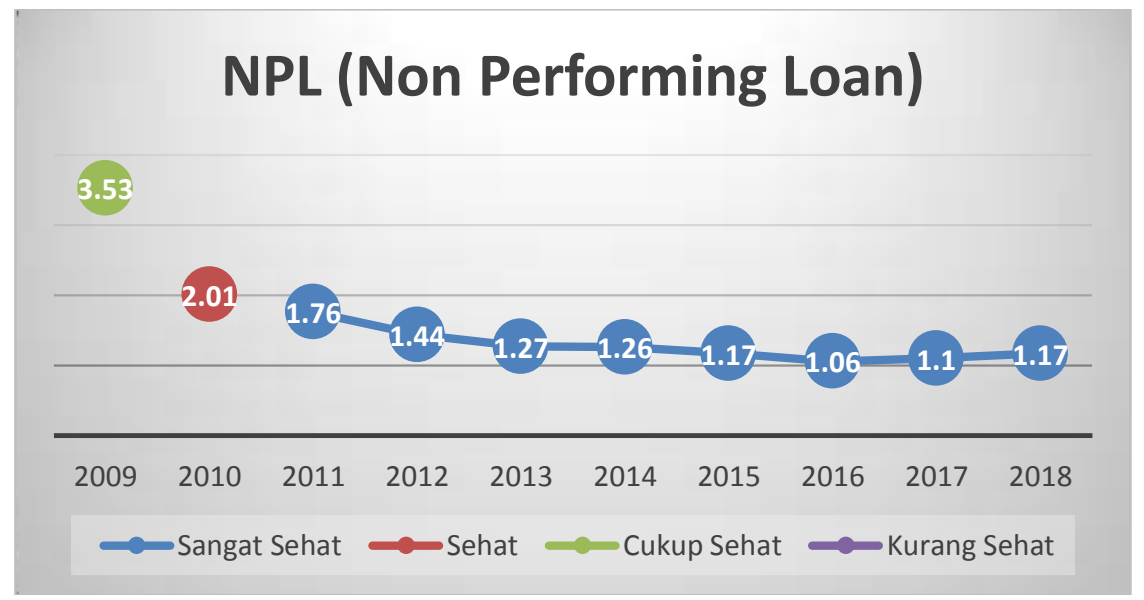

Sumber : Data diolah (2019)

Dilihat dari hasil perhitungan tabel diatas, diketahui bahwa Nilai rerata Net Profit Loan PT. BRI, Tbk selama tahun 2009-2018 adalah 1,58\%. Nilai NPL berada pada kondisi yang sangat sehat. Itu artinya PT. BRI, Tbk mampu menjaga kulaitas kredit dengan baik selama tahun penelitian. 
b. Loan to Deposit Ratio/LDR

Rasio ini membandingkan total kredit dengan dana pihak ketiga non bank (seperti: tabungan, giro,dan deposito berjangka). Berikut adalah hasil perhitungan LDR PT. BRI, Tbk

Tabel Tingkat Kesehatan BRI tahun 2008-2018 berdasarkan Rasio LDR

\begin{tabular}{|c|c|c|c|c|c|}
\hline Tahun & Total Kredit & $\begin{array}{c}\text { Dana } \\
\text { Pihak Ketiga }\end{array}$ & LDR & Predikat & Peringkat \\
\hline 2009 & 205.037 .003 & 254.117 .950 & 80,69 & Sehat & 2 \\
\hline 2010 & 246.964 .238 & 328.555 .801 & 75,17 & Sehat & 2 \\
\hline 2011 & 285.406 .257 & 374.913 .340 & 76,13 & Sehat & 2 \\
\hline 2012 & 350.758 .262 & 439.202 .137 & 79,86 & Sehat & 2 \\
\hline 2013 & 434.316 .466 & 490.486 .513 & 88,55 & Cukup Sehat & 3 \\
\hline 2014 & 495.097 .288 & 605.610 .330 & 81,75 & Sehat & 2 \\
\hline 2015 & 564.480 .538 & 649.372 .612 & 86,93 & Cukup Sehat & 3 \\
\hline 2016 & 643.470 .975 & 732.558 .804 & 87,84 & Cukup Sehat & 3 \\
\hline 2017 & 718.982 .668 & 815.367 .842 & 88,18 & Cukup Sehat & 3 \\
\hline 2018 & 820.010 .157 & 915.430 .199 & 89,58 & Cukup Sehat & 3 \\
\hline \multicolumn{2}{|r|}{ Nilai rerata } & 83,47 & Sehat & $\mathbf{2}$ \\
\hline
\end{tabular}

Sumber : data sekunder diolah (2019)

Dan dari tabel diatas dapat digambarkan dalam bentuk grafik berikut ini.

\section{LDR (Loan Deposit Ratio)}

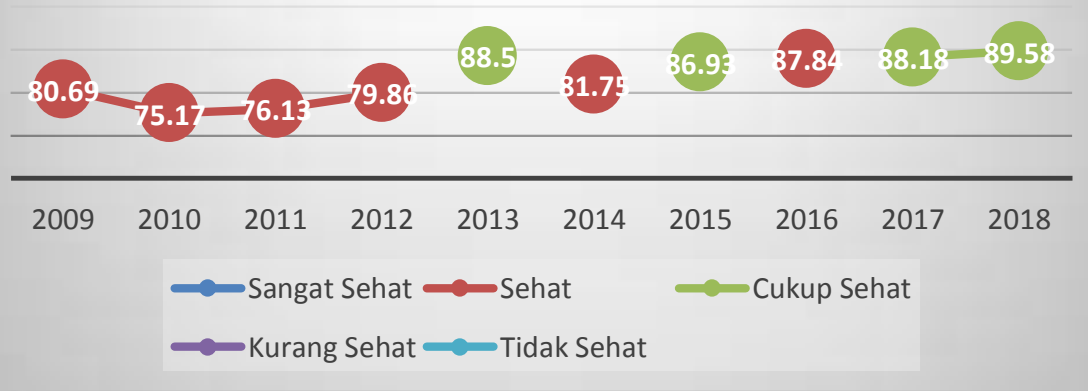

Sumber : data diolah (2019)

Nilai rerata LDR PT. BRI, Tbk periode tahun 2009-2018 adalah 83,47\%. Nilai LDR kualitas kreditnya berada pada kondisi sehat. Itu artinya bahwa PT. BRI, Tbk mampu dalam memenuhi kewajiban jangka pendeknya saat ditagih. 


\section{Good Corporate Governance/GCG}

Pemberian kriteria GCG dilakukan oleh bank secara self assesment namun tetap dipantau Bank sentral (bank Indonesia). Berikut hasil self assesment yang dilakukan oleh PT. BRI, Tbk periode 2009-2018.

Tabel Tingkat Kesehatan PT. BRI, Tbk tahun 2009-2018 berdasarkan GCG.

\begin{tabular}{|c|c|c|c|}
\hline TAHUN & GCG & PREDIKAT & PERINGKAT \\
\hline 2009 & 1,35 & Sangat Baik & 1 \\
\hline 2010 & 1,45 & Sangat Baik & 1 \\
\hline 2011 & 1,3 & Sangat Baik & 1 \\
\hline 2012 & 1,31 & Sangat Baik & 1 \\
\hline 2013 & 1,29 & Sangat Baik & 1 \\
\hline 2014 & 1,14 & Sangat Baik & 1 \\
\hline 2015 & 1,17 & Sangat Baik & 2 \\
\hline 2016 & 2 & Baik & 2 \\
\hline 2017 & 2 & Baik & 1 \\
\hline 2018 & 2 & Baik & Sangat Sehat \\
\hline RATA2 & 1,5 & \multicolumn{3}{|c|}{ Sumber : Data Annual Report BRI periode 2009-2018 } \\
\hline \multicolumn{5}{|c|}{}
\end{tabular}

Selain menggunakan tabel, rasio GCG PT. BRI, Tbk, dapat digambarkan seperti grafik berikut:

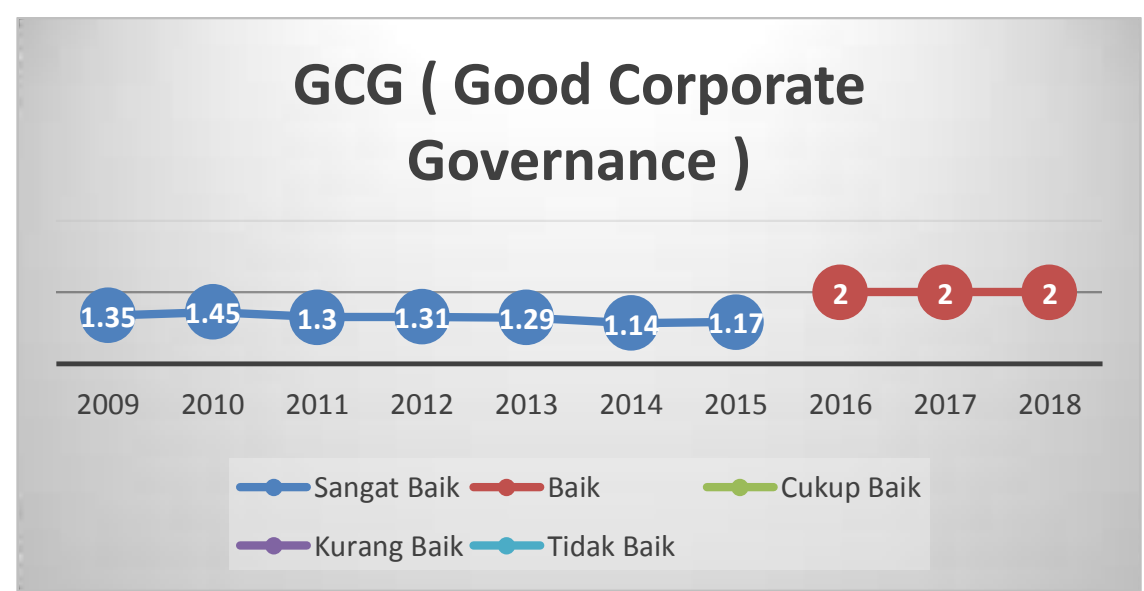

Sumber : Data Annual Report BRI periode 2009-2018

Dari tabel dan grafik diatas Tingkat kesehatan bank jika ditinjau dari nilai rerata GCG PT. BRI, Tbk selama tahun 2009-2018 adalah 1,50. Nilai ini menunjukkan kualitas manajemen PT. BRI, Tbk atas pelaksanaan prinsip GCG berjalan dengan sangat baik. Penerapan GCG yang baik akan meningkatkan kepercayaan stakeholder untuk melakukan transaksi pada PT. BRI, Tbk karena dengan melihat nilai GCG para stakeholder dapat mengetahui resiko yang mungkin terjadi apabila melakukan transaksi dengan bank tersebut. 


\section{Rentabilitas (Earnings)}

Untuk menghitung rentabilitas/earning menggunakan rasio Return On Asset/ROA dan Net Interest MarginNIM.

a. Return On Asset/ROA

$R O A$ merupakan rasio ini menunjukan kemampuan suatu bank dalam menghasilkan profit dengan memaksimalkan asset yang dimiliki. Berikut adalah menghitung rasio $\mathrm{ROA}$ :

Tabel Tingkat Kesehatan BRI tahun 2009-2018 berdasarkan ROA

\begin{tabular}{|l|l|l|l|l|c|}
\hline TAHUN & $\begin{array}{l}\text { LABA } \\
\text { SEBELUM } \\
\text { PAJAK }\end{array}$ & TOTAL ASET & ROA & PREDIKAT & PERINGKAT \\
\hline 2009 & 9.891 .228 & 316.947 .029 & 3,12 & Sangat Sehat & 1 \\
\hline 2010 & 14.908 .230 & 404.285 .602 & 3,69 & Sangat Sehat & 1 \\
\hline 2011 & 18.755 .880 & 469.899 .284 & 3,99 & Sangat Sehat & 1 \\
\hline 2012 & 23.859 .572 & 551.336 .790 & 4,33 & Sangat Sehat & 1 \\
\hline 2013 & 27.910 .066 & 626.100 .633 & 4,46 & Sangat Sehat & 1 \\
\hline 2014 & 30.804 .112 & 801.984 .190 & 3,84 & Sangat Sehat & 1 \\
\hline 2015 & 32.494 .018 & 878.426 .312 & 3,70 & Sangat Sehat & 1 \\
\hline 2016 & 34.047 .035 & 1.004 .801 .673 & 3,39 & Sangat Sehat & 1 \\
\hline 2017 & 37.023 .236 & 1.127 .447 .489 & 3,28 & Sangat Sehat & 1 \\
\hline 2018 & 41.753 .694 & 1.296 .898 .292 & 3,22 & Sangat Sehat & 1 \\
\hline \multicolumn{7}{|c|}{ Nilai rerata } & 3,70 & $\begin{array}{c}\text { Sangat } \\
\text { Sehat }\end{array}$ & 1 \\
\hline
\end{tabular}

Sumber : Data Sekunder yang diolah peneliti, 2019

Rasio ROA juga dapat digambarkan dalam bentuk grafik berikut:

\section{ROA (Return On Asset)}

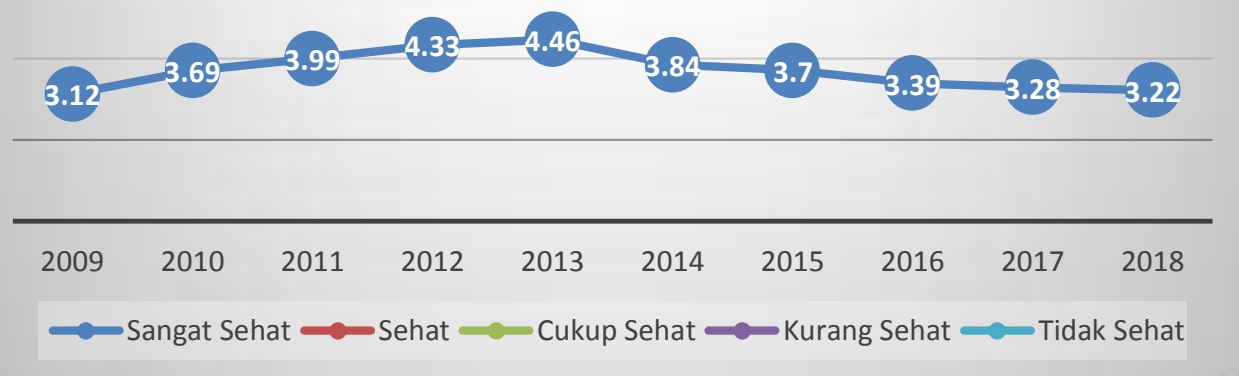

Sumber : data diolah (2019)

Gambar Grafik ROA PT. BRI, Tbk 
Berdasarkan tabel diatas Nilai rerata ROA PT. BRI, Tbk selama tahun 2009-2018 adalah 3,70\%. Dengan nilai tersebut itu artinya PT. BRI, Tbk. Mampu memperoleh laba dengan asset yang dimilikinya sesuai dengan penetapan peringkat ROA dimana rasio $>2 \%$ tergolong kriteria sangat sehat.

b. Perhitungan Net Interest Margin

Net Interest Margin/NIM untuk mengukur seberapa besar perbedaan pendapatan dari bunga yang dihasilkan dengan nilai Bungan yang telah dibayarkan. Berikut adalah hasil perhitungan NIM pada PT. BRI, Tbk

Tabel Tingkat Kesehatan BRI tahun 2009-2018 berdasarkan rasio NIM.

\begin{tabular}{|l|l|l|l|l|c|}
\hline TAHUN & $\begin{array}{l}\text { PENDAPATAN } \\
\text { BUNGA } \\
\text { BERSIH }\end{array}$ & $\begin{array}{l}\text { TOTAL } \\
\text { AKTIVA } \\
\text { PRODUKTIF }\end{array}$ & NIM & PREDIKAT & PERINGKAT \\
\hline 2009 & 23.049 .495 & 299.063 .000 & 7,71 & Sangat Sehat & 1 \\
\hline 2010 & 32.888 .603 & 379.696 .000 & 8,66 & Sangat Sehat & 1 \\
\hline 2011 & 34.427 .076 & 432.647 .000 & 7,96 & Sangat Sehat & 1 \\
\hline 2012 & 36.483 .766 & 499.042 .000 & 7,31 & Sangat Sehat & 1 \\
\hline 2013 & 44.106 .271 & 568.546 .000 & 7,76 & Sangat Sehat & 1 \\
\hline 2014 & 51.442 .410 & 728.094 .000 & 7,07 & Sangat Sehat & 1 \\
\hline 2015 & 58.279 .767 & 781.931 .000 & 7,45 & Sangat Sehat & 1 \\
\hline 2016 & 65.439 .190 & 991.719 .000 & 6,60 & Sangat Sehat & 1 \\
\hline 2017 & 73.018 .094 & 1.128 .476 .000 & 6,47 & Sangat Sehat & 1 \\
\hline 2018 & 77.665 .772 & 1.178 .512 .000 & 6,59 & Sangat Sehat & 1 \\
\hline \multicolumn{7}{|c}{ Nilai rerata } & 7,36 & Sangat & Sehat & 1 \\
\hline
\end{tabular}

Sumber : data diolah (2019)

Selain dalam bentuk tabel, juga dapat dibuat grafik seperti berikut.

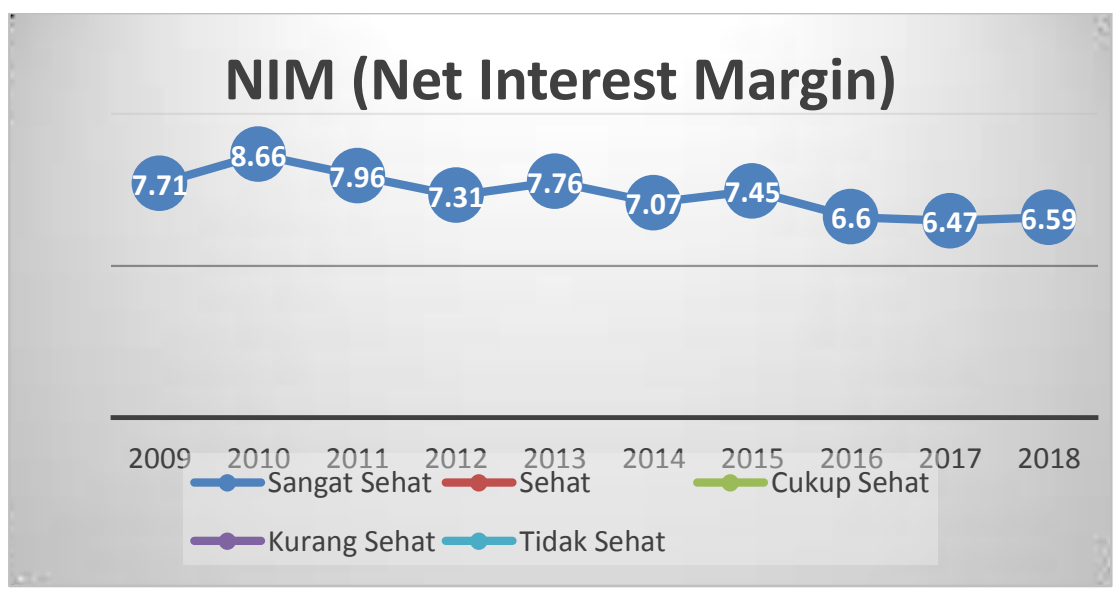

Sumber : data diolah (2019)

Gambar Grafik NIM PT. BRI, Tbk

Berdasarkan tabel diatas Nilai rata-rata NIM PT. Bank Rakyat Indonesia, Tbk selama tahun 2009-2018 adalah 7,36\%. Nilai NIM tersebut menunjukkan kemampuan manajemen bank yang sangat baik dalam mengelola aktiva produktifnya untuk menghasilkan pendapatan bunga bersih perusahaan. Hal ini sesuai dengan matriks penetapan peringkat NIM dimana rasio $3 \%>\mathrm{NIM}$ masuk dalam kriteria sangat sehat. 
ISSN (print) : 2598-9545 \& ISSN (online) : 2599-171X

\section{Perhitungan rasio Permodalan (Capita)}

Dalam perhitungan rasio permodalan menggunakan rasio Modal, rasio CAR, dan rasio Aset Tertimbang Menurut Risiko (ATMR) berpedoman pada ketentuan $\mathrm{BI}$ mengenai Kewajiban Penyediaan Modal Minimum Bank Umum/KPMM. Berikut adalah hasil perhitungan rasio CAR.

Tabel Kesehatan PT. BRI, Tbk tahun 2009-2018 berdasarkan rasio CAR.

\begin{tabular}{|l|l|l|l|l|c|}
\hline TAHUN & MODAL & ATMR & CAR & PREDIKAT & PERINGKAT \\
\hline 2009 & 22.839 .021 & 173.068 .002 & 13,20 & Sangat Sehat & 1 \\
\hline 2010 & 31.710 .589 & 230.447 .032 & 13,76 & Sangat Sehat & 1 \\
\hline 2011 & 41.815 .988 & 279.602 .642 & 14,96 & Sangat Sehat & 1 \\
\hline 2012 & 55.133 .677 & 325.352 .028 & 16,95 & Sangat Sehat & 1 \\
\hline 2013 & 69.472 .036 & 408.858 .393 & 16,99 & Sangat Sehat & 1 \\
\hline 2014 & 85.706 .557 & 468.182 .076 & 18,31 & Sangat Sehat & 1 \\
\hline 2015 & 110.580 .617 & 537.074 .938 & 20,59 & Sangat Sehat & 1 \\
\hline 2016 & 142.910 .432 & 623.857 .728 & 22,91 & Sangat Sehat & 1 \\
\hline 2017 & 161.751 .934 & 704.515 .985 & 22,96 & Sangat Sehat & 1 \\
\hline 2018 & 173.618 .421 & 818.608 .240 & 21,21 & Sangat Sehat & 1 \\
\hline \multicolumn{7}{|c|}{ RATA-RATA } & 18,18 & Sangat & Sehat & 1 \\
\hline
\end{tabular}

Sumber : data diolah (2019)

Dari tabel diatas, dapat dibuat grafik berikut:

\section{CAR (Capital Adequacy Ratio)}

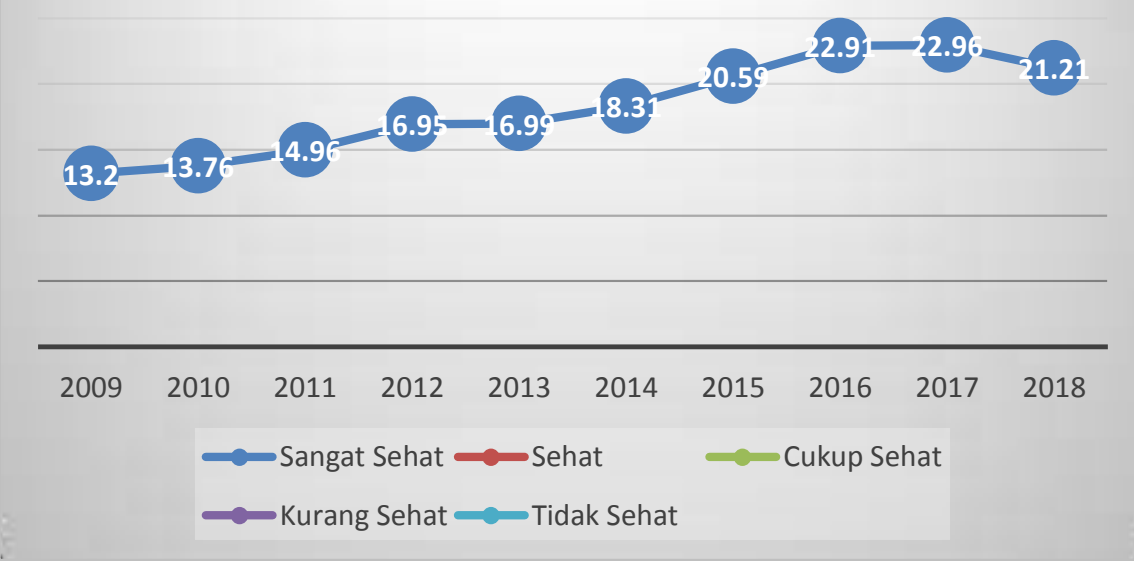

Sumber : data diolah (2019)

Gambar Grafik CAR PT. BRI, Tbk

Tingkat kesehatan bank ditinjau dari aspek permodalan dengan mengitung CAR pada PT. BRI, Tbk periode 2009-2018 memiliki nilai ratarata CAR $18,18 \%$ dengan kriteria sangat sehat. CAR yang tinggi menunjukkan bank dapat mengatasi kerugian operasional bank tersebut bila terdapat pemberian kredit yang besar. Nilai CAR pada PT. BRI, Tbk selama periode yang diteliti berada di atas standar yang telah ditetapkan 
sehingga bank dinilai telah mampu memenuhi Kewajiban Penyediaan Modal Minimum/KPMM.

\section{Perhitungan AspekRisk Profile, Good Corporate Governance, Earnings, Capital (RGEC)}

Berikut adalah hasil perhitungan RGCE pada PT. BRI, Tbk

Tabel Penetapan Peringkat Komposit PT. BRI, Tbk dengan metode RGEC periode 2009-2018.

\begin{tabular}{|c|c|c|c|c|c|c|c|c|c|c|c|}
\hline \multirow{2}{*}{ Tahun } & \multirow{2}{*}{ Komponen Faktor } & \multirow{2}{*}{ Rasio } & \multirow{2}{*}{ Nilai } & \multicolumn{5}{|c|}{ Kriteria } & \multirow{2}{*}{ Kriteria } & \multirow{2}{*}{ Ket } & \multirow{2}{*}{ PK } \\
\hline & & & & 1 & 2 & 3 & 4 & 5 & & & \\
\hline \multirow{7}{*}{2009} & \multirow{2}{*}{ Risk Profile } & NPL & $3,53 \%$ & & $\sqrt{ }$ & & & & Sehat & \multirow{2}{*}{ Sehat } & \multirow{7}{*}{$\begin{array}{c}\text { Sangat } \\
\text { Sehat }\end{array}$} \\
\hline & & LDR & $80,69 \%$ & & $\sqrt{ }$ & & & & Sehat & & \\
\hline & GCG & GCG & 1,35 & $\sqrt{ }$ & & & & & $\begin{array}{c}\text { Sangat } \\
\text { Sehat }\end{array}$ & $\begin{array}{c}\text { Sangat } \\
\text { Sehat }\end{array}$ & \\
\hline & \multirow{2}{*}{ Rentabilitas/Earnings } & ROA & $3,12 \%$ & $\sqrt{ }$ & & & & & $\begin{array}{c}\text { Sangat } \\
\text { Sehat }\end{array}$ & \multirow{2}{*}{$\begin{array}{c}\text { Sangat } \\
\text { Sehat }\end{array}$} & \\
\hline & & NIM & $7,71 \%$ & $\sqrt{ }$ & & & & & $\begin{array}{c}\text { Sangat } \\
\text { Sehat }\end{array}$ & & \\
\hline & permodalan & CAR & $13,20 \%$ & $\sqrt{ }$ & & & & & $\begin{array}{l}\text { Sangat } \\
\text { Sehat }\end{array}$ & $\begin{array}{c}\text { Sangat } \\
\text { Sehat }\end{array}$ & \\
\hline & \multicolumn{2}{|l|}{ Nilai Komposit } & 30 & 20 & 8 & & & & \multicolumn{2}{|c|}{$(28 / 30)^{*} 100 \%=93,34 \%$} & \\
\hline \multirow{7}{*}{2010} & \multirow{2}{*}{ Risk Profile } & NPL & $2,01 \%$ & & $\sqrt{ }$ & & & & Sehat & \multirow{2}{*}{ Sehat } & \multirow{7}{*}{$\begin{array}{l}\text { Sangat } \\
\text { Sehat }\end{array}$} \\
\hline & & LDR & $75,17 \%$ & & $\sqrt{ }$ & & & & Sehat & & \\
\hline & GCG & GCG & 1,45 & $\sqrt{ }$ & & & & & $\begin{array}{l}\text { Sangat } \\
\text { Sehat }\end{array}$ & $\begin{array}{c}\text { Sangat } \\
\text { Sehat }\end{array}$ & \\
\hline & \multirow{2}{*}{ Earnings } & ROA & $3,69 \%$ & $\sqrt{ }$ & & & & & $\begin{array}{l}\text { Sangat } \\
\text { Sehat }\end{array}$ & \multirow{2}{*}{$\begin{array}{c}\text { Sangat } \\
\text { Sehat }\end{array}$} & \\
\hline & & NIM & $8,66 \%$ & $\sqrt{ }$ & & & & & $\begin{array}{l}\text { Sangat } \\
\text { Sehat }\end{array}$ & & \\
\hline & Capital & CAR & $13,76 \%$ & $\sqrt{ }$ & & & & & $\begin{array}{c}\text { Sangat } \\
\text { Sehat }\end{array}$ & $\begin{array}{c}\text { Sangat } \\
\text { Sehat }\end{array}$ & \\
\hline & \multicolumn{2}{|l|}{ Nilai Komposit } & 30 & 20 & 8 & & & & \multicolumn{2}{|c|}{$(28 / 30)^{*} 100 \%=93,34 \%$} & \\
\hline \multirow{7}{*}{2011} & \multirow{2}{*}{ Risk Profile } & NPL & $1,76 \%$ & $\sqrt{ }$ & & & & & Sehat & \multirow{2}{*}{ Sehat } & \multirow{7}{*}{$\begin{array}{l}\text { Sangat } \\
\text { Sehat }\end{array}$} \\
\hline & & LDR & $76,13 \%$ & & $\sqrt{ }$ & & & & Sehat & & \\
\hline & GCG & GCG & 1,3 & $\sqrt{ }$ & & & & & $\begin{array}{l}\text { Sangat } \\
\text { Sehat }\end{array}$ & $\begin{array}{c}\text { Sangat } \\
\text { Sehat }\end{array}$ & \\
\hline & \multirow{2}{*}{ Earnings } & ROA & $3,99 \%$ & $\sqrt{ }$ & & & & & $\begin{array}{c}\text { Sangat } \\
\text { Sehat }\end{array}$ & \multirow{2}{*}{$\begin{array}{c}\text { Sangat } \\
\text { Sehat }\end{array}$} & \\
\hline & & NIM & $7,96 \%$ & $\sqrt{ }$ & & & & & $\begin{array}{l}\text { Sangat } \\
\text { Sehat }\end{array}$ & & \\
\hline & Capital & CAR & $14,96 \%$ & $\sqrt{ }$ & & & & & $\begin{array}{c}\text { Sangat } \\
\text { Sehat }\end{array}$ & $\begin{array}{c}\text { Sangat } \\
\text { Sehat }\end{array}$ & \\
\hline & Nilai Komposit & & 30 & 25 & 4 & & & & $(29 / 30) * 10$ & $=96,67 \%$ & \\
\hline & Risk Profile & NPL & $1,44 \%$ & $\sqrt{ }$ & & & & & $\begin{array}{c}\text { Sangat } \\
\text { Sehat }\end{array}$ & Sangat & \\
\hline & & LDR & $79,86 \%$ & & $\sqrt{ }$ & & & & Sehat & & \\
\hline 2012 & GCG & GCG & 1,31 & $\sqrt{ }$ & & & & & $\begin{array}{c}\text { Sangat } \\
\text { Sehat }\end{array}$ & $\begin{array}{c}\text { Sangat } \\
\text { Sehat }\end{array}$ & Sehat \\
\hline & Earnings & ROA & $4,33 \%$ & $\sqrt{ }$ & & & & & $\begin{array}{l}\text { Sangat } \\
\text { Sehat }\end{array}$ & $\begin{array}{c}\text { Sangat } \\
\text { Sehat }\end{array}$ & \\
\hline
\end{tabular}









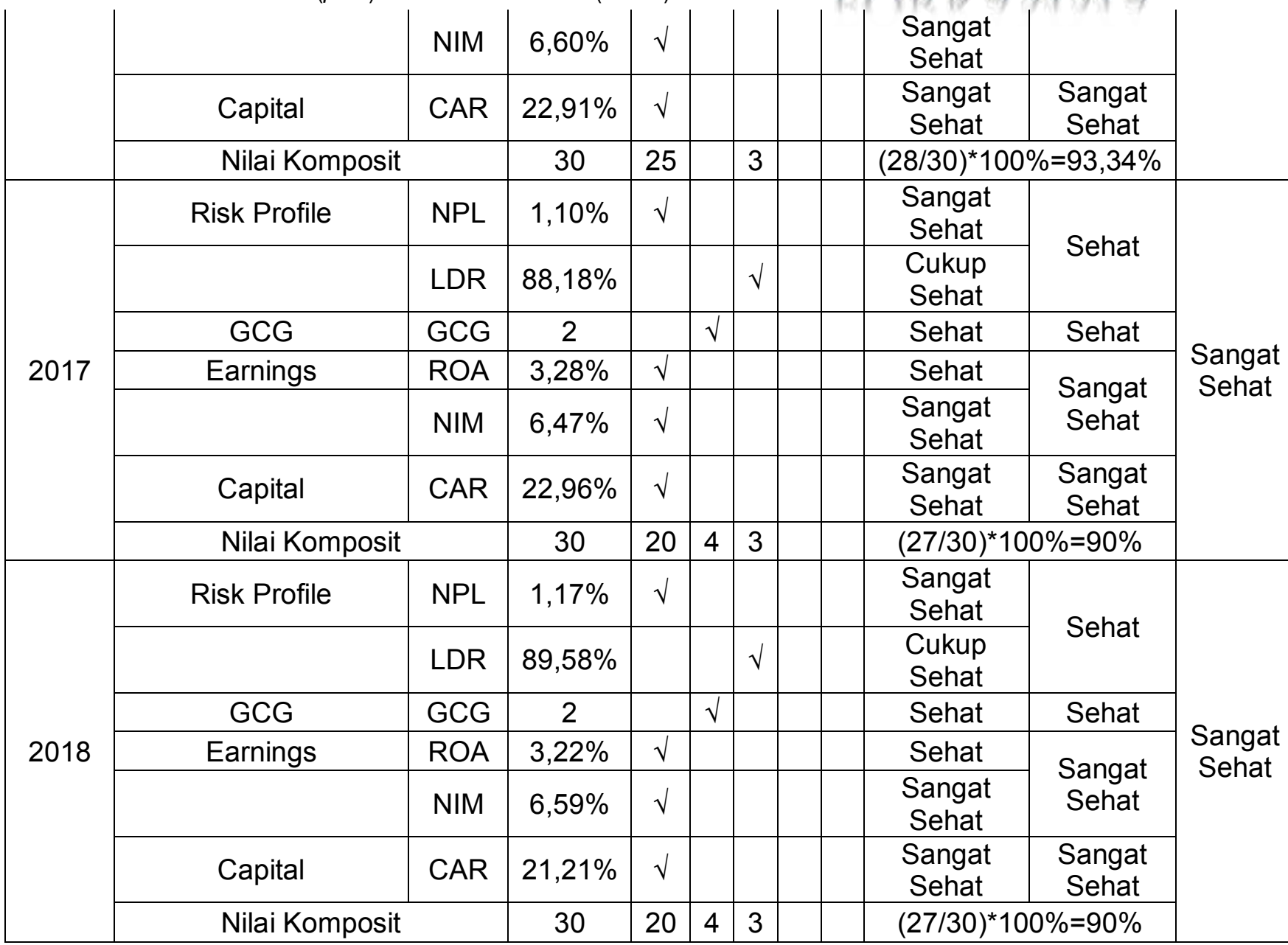

Sumber : data diolah (2019)

Hasil perhitungan dan analisis tingkat kesehatan PT. BRI, Tbk dengan menggunakan metode RGEC periode 2009-2018 menunjukkan bahwa kinerja bank berada pada Peringkat Komposit 1 (PK-1). yaitu terlihat dari keempat aspek yang diukur berupa Risk Profile, Good Corporate Governance, Earnings, Capital secara keseluruhan berada dalam peringkat sangat sehat. Hal ini menunjukkan bahwa PT. BRI, Tbk terus mempertahankan kinerja perusahaan secara keseluruhan sehingga tetap berada pada peringkat yang sangat sehat dan bila perlu lebih ditingaktkan lagi.

\section{E. KESIMPULAN}

Berdasarkan hasil penelitian diatas, dapat disimpulkan bahwa:

1. Hasil penilaian Tingkat Kesehatan Bank pada PT. BRI, Tbk ditinjau dari Risk Profile periode 2009-2018.

Dari Hasil perhitungan bahwa penilaian Profil risiko (Risk profile) PT. Bank Rakyat Indonesia, Tbk menggunakan rasio NPL dan risiko likuiditas dengan rasio LDR selama tahun 2009-2018 berada dalam kondisi yang sehat. Hal ini terbukti dengan nilai ratarata NPL PT. Bank Rakyat Indonesia, Tbk selama tahun 2009-2018 adalah 1,58\% berada dalam kondisi sangat sehat. Sedangkan nilai rata-rata LDR PT. Bank Rakyat Indonesia, Tbk selama tahun $2009-2018$ 83,47\% berada dalam kondisi sehat. 
2. Hasil Penilaian Tingkat Kesehatan Bank pada PT. BRI, Tbk ditinjau dari Good Corporate Governance periode 2009-2018.

Hasil penilaian Good Corporate Governance (GCG PT. BRI, Tbk periode 20092018 diperoleh nilai rerata 1,50 berada pada tingkat 1 (satu) yang artinya pelaksanaan prinsip-prinsip GCG telah terlaksana dengan sangat baik.

3. Hasil Penilaian Tingkat Kesehatan PT. BRI, Tbk ditinjau dari (Earnings) periode 20092018.

Sesuai dengan Hasil perhitungan bahwa penilaian Rentabilitas/Earning PT. BRI, Tbk dengan menggunakan rasio ROA dan NIM selama periode tahun 2009-2018 berada dalam kondisi sangat sehat. Hal ini terbukti dengan nilai rata-rata ROA PT. BRI, Tbk selama periode tahun $2009-2018$ adalah $3,70 \%$ berada dalam kondisi sangat sehat. Selanjutnya nilai rerata NIM pada PT. BRI, Tbk selama periode 2009-2018 adalah $7,36 \%$ berada dalam kondisi sangat sehat. Nilai rerata ROA dan NIM yang diperoleh PT. BRI, Tbk tersebut menunjukkan bahwa PT. BRI, Tbk telah berhasil menjalankan kegiatan operasional perusahaan dengan efektif sehingga mampu menghasilkan profitabilitas yang tinggi selama periode tahun 2009-2018.

4. Penilaian Tingkat Kesehatan Bank pada PT. BRI, Tbk ditinjau dari (Capital) pada periode tahun 2009-2018.

Hasil penilaian Permodalan (Capital) PT PT. BRI, Tbk selama periode tahun 20092018 berada dalam kondisi sangat sehat, hal ini dibuktikan dengan rerata CAR PT. BRI, Tbk selama $2009-2018$ adalah $18,18 \%$ dengan kriteria sangat sehat. Nilai ratarata CAR tersebut berada di atas standar minimal CAR yang telah ditetapkan oleh Bank BI yaitu sebesar $8 \%$, hal ini menunjukkan selama periode tersebut PT. BRI, Tbk telah mampu mengelola capital perusahaan dengan sangat baik.

5. Hasil perhitungan bahwa Penilaian Tingkat Kesehatan Bank pada PT. BRI, Tbk ditinjau dari aspek RGEC (Risk profile, Good Corporate Governance, Earnings, dan Capital) pada tahun 2009-2018.

Hasil penilaian tingkat kesehatan PT. Bank Rakyat Indonesia, Tbk dilihat dari aspek RGEC (Risk profile, GCG, Earnings, dan Capital) selama periode tahun 2009-2018 menempati Peringkat Komposit 1 (PK-1). Sehingga PT. BRI, Tbk selama periode tersebut dinilai sangat mampu menghadapi pengaruh negatif yang signifikan dari perubahan kondisi bisnis dan faktor eksternal lainnya tercermin dari kriteria faktorfaktor penilaian, antara lain risk profile, penerapan GCG, earnings, dan permodalan/capital yang secara umum sangat baik. Apabila terdapat kelemahan maka secara umum kelemahan tersebut tidak signifikan. 


\section{DAFTAR PUSTAKA}

.Abdul Kadim, K., \& Nardi, S. (2018). Pengaruh analisa kesahatan dan kebangkrutan dengan pendekatan altman z-score terhadap harga saham Industri Konstruksi di indonesia yang listing di BEl periode 2013-2017. Jurnal IImiah Saham, Ekonomi, Keuangan, dan Investasi Prodi Manajemen Universitas Pamulang, 1(4), 52-65.

Abdul Kadim, K., Nardi Sunardi, S., Hendro Waryanto, W., Dessy Adelin, A., \& Endang Kusmana, K. (2018). The Effects Of Bank Soundness With The RGEC Approach (Risk Profile, Good Corporate Governance, Earnings, Capital) Of Leverage And Its Implications On Company's Value Of State Bank In Indonesia For The Period Of 2012-2016. IJER (International Journal of Economic Research), 15(11), 41-52.

Abdul, K., \& Nardi, S. (2018). Analisis altman z-score untuk memprediksi kebangkrutan pada Bank Pemerintah (BUMN) di Indonesia Tahun 2012-2016. Jurnal IImiah Sekuritas Prodi Manajemen Universitas Pamulang, 1(3), 142-156.

Irham Fahmi. (2015). "Pengantar Manajemen Keuangan”. Bandung. Alfabeta.

Kasmir. Edisi Revisi. 2014. "Dasar-Dasar Perbankan”. Jakarta. Raja Grafindo.

Mudrajat dan Suhardjono. 2011. "Manajemen Perbankan Teori dan Aplikasi". Yogyakrta: BPFE.

Peraturan Bank Indonesia. 2011. Peraturan Bank Indonesia No. 13/PBI/2011, tentang tata cara penilaian kesehatan bank umum

Permana, Bayu Aji. 2012. "Analisis Tingkat Kesehatan Bank Berdasarkan Metode CAMELS dan Metode RGEC". Skripsi. Universitas Negeri Surabaya. Surabaya.

Rivai, Veithzal, dkk. 2012. "Commercial Bank Management:Manajemen Perbankan dari Teori ke Praktik". PT Raja Grafindo Persada. Jakarta.

Sadiyah, K., Nurita, E., \& Lesmana, R. (2020). Pelatihan Manajemen Keuangan Bagi Nelayan Kepulauan Seribu Pasca Penjualan Hasil Tangkapan IKAN. Jurnal Abdimas, 1(1).

SE BI No. 6/23/DPNP Perihal: Sistem Penilaian Tingkat Kesehatan Bank Umum. Jakarta: Bank Indonesia.

SE BI. 2011. Surat Edaran Bank Indonesia No. 13/24/DPNP tanggal 25 Oktober 2011, tentang Matriks Perhitungan Analisis Komponen Faktor Analisis RGEC untuk Bank Umum.

Sunardi, N. (2018). Analisis Du Pont System Dengan Time Series Approach (Tsa) Dan Cross Sectional Approach (Csa) Dalam Penilaian Kinerja Keuangan Perusahaan (Studi Pada Industri Konstruksi (BUMN) di Indonesia Yang Listing di BEI Tahun 2013-2017). Jurnal SEKURITAS (Saham, Ekonomi, Keuangan dan Investasi), 1(4).

Sunardi, N. (2018). Analisis Economic Value Added (Eva), Financial Value Added (FVA) Dan Market Value Added (MVA) Dengan Time Series Approach Sebagai Alat Penilaian Kinerja Keuangan (Studi Pada Industri Konstruksi (BUMN) di Indonesia Yang Listing di BEI Tahun 2013-2017). Jurnal SEKURITAS (Saham, Ekonomi, Keuangan dan Investasi), 2(1).

Sunardi, N. (2018). Analisis Risk Based Bank Rating (RBBR) Untuk Mengukur Tingkat Kesehatan Bank Syariah Di Indonesia. JIMF (Jurnal IImiah Manajemen Forkamma), 1(2).

Sunardi, N. (2020). Kesehatan Bank Umum Syariah yang terdaftar di Otoritas Jasa Keuangan dengan metode Risk Based Bank Rating (RBBR). Jurnal SEKURITAS (Saham, Ekonomi, Keuangan dan Investasi), 3(2), 11-16.

Sunardi, N. S. N., Lesmana, R., \& Tumanggor, M. (2018). Implementasi Manajemen Dalam Meningkatkan Iman dan Taqwa Masyarakat Dusun Panyeredan, Cimanggu, Cisalak, Subang-Jawa Barat. Jurnal Pengabdian Dharma Laksana, 1(1).

Sunardi, N., \& Oktaviani, L. (2016). Analisis Camel Dalam Menilai Tingkat Kesehatan Bank (Studi Kasus pada Subsektor Perbankan yang Terdaftar di BEI Periode 20112015). Jurnal IImiah IImu Manajemen. 